\title{
Experimental Organism Increased Number of Glial Cells
}

National Cancer Institute

\section{Source}

National Cancer Institute. Experimental Organism Increased Number of Glial Cells. NCI

Thesaurus. Code C161564.

Increase in the number of glial cells. 